\title{
Evaluation of patient follow-up with transient hypogammaglobulinemia in infancy diagnosis
}

\section{Süt çocuğunun geçici hipogamaglobulinemi tanısı ile takip edilen hastaların değerlendirilmesi}

\author{
(1) Alaaddin Yorulmaz, ${ }^{1}$ 이 Hasibe Artaç, ${ }^{2}$ (1) İsmail Reisli ${ }^{3}$ \\ 'Department of Pediatrics, Selçuk University Faculty of Medicine, Konya, Turkey \\ ${ }^{2}$ Department of Pediatric Immunology and Allergy, Selcuk University Faculty of Medicine, Konya, Turkey \\ ${ }^{3}$ Department of Pediatric Immunology and Allergy, Necmeddin Erbakan University Meram Faculty of Medicine, Konya, Turkey
}

\begin{abstract}
Introduction: In this study, we aimed to investigate the clinical, laboratory and demographic characteristics of patients with THI who were admitted with the suspicion of recurrent infection and immunodeficiency. Methods: The study included 287 patients who were followed up with the diagnosis of transient hypogammaglobulinemia in infancy at Selçuk University Meram Faculty of Medicine, Child Health and Diseases Department and Department of Pediatric Allergy and Immunology, between November 2001 and November 2006. The age, gender, the age of the complaints and diagnosis, clinical features, family history and laboratory findings of the patients were examined. The data of the patients were collected by using the hospital file and the records in the Pediatric Immunology cards.
\end{abstract}

Results: 195 (67.9\%) of the patients were male and 92 (32.1\%) were female $(p<0.05)$. The $M / F$ ratio was 2.1. The age of diagnosis ranged from 8 months to 48 months with a mean of $24.6 \pm 11.3$ months. The duration between the complaints and the age of diagnosis was between 1 and 63 months and the mean age was $13.5 \pm 8.6$ months. Complaints of the patients were recurrent upper respiratory tract infection (URTI) $54.35 \%$ (n: 156), lower respiratory tract infection (LRTI) 50.52\% (n: 145), sinusitis $41.26 \%$ (n: 118), recurrent otitis, $28.22 \%$ (n: 81 ), asthma finding $12.89 \%$ $(n=37)$, allergic skin and rhinitis findings $10.45 \%(n: 30)$, gastroenteritis $6.96 \%$ ( $n: 20)$, urinary tract infection $4.18 \%$ ( $n: 12)$, and moniliazis was $3.83 \%$ (n: 11$)$.

Discussion and Conclusion: THI is usually a self-recovering disease around three years of age. In order to prevent complications such as chronic lung disease and to reduce morbidity, it is important to follow up the cases regularly.

Keywords: Immunodeficiency; infancy; transient hypogammaglobunemia.
Özet

Amaç: Bu çalışmada kliniğimize tekrarlayan enfeksiyon ve immün yetmezlik şüphesi ile başvuran THI'li olguların klinik, laboratuvar ve demografik özelliklerini incelemeyi amaçladık.

Gereç ve Yöntem: Çalışmaya, Selçuk Üniversitesi Meram Tıp Fakültesi Çocuk Sağlığı ve Hastalıkları Anabilim dalı, Pediatrik Allerji ve İmmünoloji bölümünde Kasım 2001- Kasım 2006 tarihleri arasında süt çocukluğunun geçici hipogamaglobülinemi tanısı ile izlenen 287 hasta alındı. Hastaların yaş, cinsiyet, şikayetlerinin başladığı yaş ve tanı yaşları, klinik özellikleri, aile öyküsü, laboratuar bulguları incelendi. Hastalara ait veriler, hastane dosyası ve Pediatrik Immünoloji kartlarındaki kayıtları kullanılarak toplandı.

Bulgular: Çalışmaya alınan hastaların 195'i $(\% 67,9)$ erkek, 92'si $(\% 32,1) \mathrm{kız} \mathrm{idi}(p<0,05)$. E/K oranı 2,1 idi. Tanı yaşı 8 ay ile 48 ay arasın-

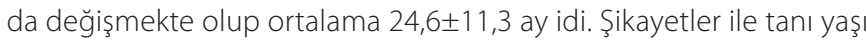
arasındaki geçen süre 1-63 ay arasında olup ortalama 13,5 $\pm 8,6$ ay idi. Hastaların başvuru şikayetleri tekrarlayan ÜSYE \%54,35 (n: 156), ASYE $\% 50,52$ (n: 145), sinüzit \%41,11 (n: 118), tekrarlayan otit \%28,22 (n:81), astım bulguları \%12,89 (n: 37), alerjik cilt ve rinit bulguları \%10,45 (n: 30), gastroenterit \%6,96 (n: 20), idrar yolu enfeksiyonu \% 4,18 (n: 12), moniliazis \%3,83 (n: 11) idi.

Sonuç: THI çoğunlukla üç yaş civarında kendiliğinden düzelen bir hastalıktır. Kronik akciğer hastalığı gibi komplikasyonlarını önlemek ve morbiditeyi azaltmak için olguların düzenli takip edilmesi önemlidir.

Anahtar Sözcükler: İmmün yetmezlik; süt çocuğu; geçici hipogamaglobülinemi 
$\mathrm{T}$ he transient hypogammaglobulinemia of the infant (THI) was first identified by Gitlin and Janeway in 1956. ${ }^{[1]}$ As a result of the exclusion of other causes of hypogammaglobulinemia, it is normally considered as the period extension of physiological hypogammaglobulinemia which we expect in babies aged 3-6 months. Hypogammaglobulinemia develops due to the decrease of antibodies in the lgG structure transmitted from the mother by transplacental route and inadequate normal production of the $\lg G$ of the infant. ${ }^{[2]}$ In addition, IgA and IgM levels may also be low. Although a number of pathological mechanisms have been proposed, the causes of THI are not fully known.

The THI frequency is not fully known. While THI may be asymptomatic, recurrent sinopulmonary infections and rarely lifethreatening infections such as meningitis may be seen. ${ }^{[3]}$ In these cases, the serum IgG level is below the 2 standard deviation of the mean according to the age. Although THI has been known for a long time, very little is known about the longterm follow-up of patients. ${ }^{[4]}$ Spontaneous clinical improvement, in most of the studies, is reported to be between 9 and 15 months and normal Ig levels are reached between 2 and 4 years old. ${ }^{[3]}$ However, in a limited number of patients, low lg levels have been shown to continue until the age of $5 .^{[5,6]}$

In this study, we aimed to investigate the clinical, laboratory and demographic characteristics of cases whom we evaluated as THI after excluding other hypogammaglobulin causes and the patients who were admitted to our clinic with the suspicion of recurrent infection and immunodeficiency, followedup with a pre-diagnosis of hypogammaglobulinemia.

\section{Materials and Method}

\section{Study population}

The study included 287 patients who were followed up with the diagnosis of transient hypogammaglobulinemia in infancy at Selçuk University Meram Faculty of Medicine, Child Health and Diseases Department and Department of Pediatric Allergy and Immunology, between November 2001 and November 2006. The age, gender, the age of the complaints and diagnosis, clinical features, family history and laboratory findings of the patients were examined, retrospectively. Parental blood relatives, family history of immunodeficiency, family history about the childern who had lost their lives due to this illness, clinical conditions at admission, absolute lymphocyte counts, serum immunoglobulin levels, peripheral blood lymphocyte subgroups, in vitro lymphocyte subsets, complications during follow-up, treatments, if any, the causes of death were recorded. The data of the patients were collected by using the hospital file and the records in the Pediatric Immunology cards.

The consanguineous marriage was classified as first degree (cousins), second degree (sibling descendants) and third degree (more distant) kinship. It was accepted as growth retardation when the quantitative values which were determined according to the height and weight measurement and gender were below 2SD It was recorded whether the patients came to the hospital when they were regularly called for control at 3-month intervals repeated viral and pyogenic infections of each patient were recorded. Complete blood count and immunoglobulin values were re-evaluated.

The lung tomography was performed in patients with chronic lung disease findings. High-Resolution Computerized Tomography $(\mathrm{HRCT})$ was taken when necessary pathological radiological images were followed. In patients, allergy was detected by specific high lgE levels and/or skin prick test positivity. The following criteria were investigated for the diagnosis of $\mathrm{THI}{ }^{[7]}$

1. Patients under 4 years of age at the admission

2. One or more major lgs ( $\lg G, A, M)$ below $2 S D$ for the serum level based on the age.

3. Normal titer of isohemagglutinin (1/10 and above)

4. Solidity of cellular immunity, clinical and laboratory tests, and no other immunodeficiency syndromes.

Each patient was called for control at 3 to 6 months periods until their immunoglobulins were normal and clinically improved. In the controls, the patient's health status and laboratory tests were examined as a whole. In laboratory tests, Igs, isohemagglutinin titers (Anti- $A$, Anti-B, N: $\geq 1 / 10$ ), peripheral blood lymphocyte subgroups (CD3, CD4, CD8, CD19 and CD16+56 levels), phytohemagglutinin (PHA) lymphopoliferative response were evaluated.

\section{Methods}

Complete blood count (Beckman Coulter Gen-S, laser system) and peripheral smear were used to calculate the absolute neutrophil and lymphocyte counts. If the absolute lymphocyte count was less than $3000 / \mathrm{mm}^{3}$ under one year and below $1500 / \mathrm{mm}^{3}$ at one year of age, neutropenia was considered if lymphopenia and neutrophil count was lower than $1500 / \mathrm{mm}^{3}$. Serum immunoglobulin and its subgroups were studied by nephelometric method (Date Behring Marburg Gmbh, Germany) and the values were compared with the normal limits. Peripheral lymphocyte subgroups were analyzed using 4 color flow cytometry method (BD Facs Calibur, BD Calibur, BD Biosciences, San Jose, California, USA). In vitro lymphocyte proliferation was performed using fitohemaglutinin (Irvine Scientific, 2511 Daimler street, Santa Ana, California). The titers of isohemagglutinin were determined in the blood bank of our hospital according to the standard methods.

\section{Statistical analysis}

Statistical evaluation of the data (SPSS for Windows, Version 10.0, SPSS Inc., U.S.A) was performed using the package program. Student t-test was used for normal distribution, and Mann-Whitney $U$ test was used for the distribution which is not normal. Pearson chi-square was used to compare categorical variables. $\mathrm{P}<0.05$ was considered statistically significant. 


\section{Results}

The average number of patients who were admitted to the general outpatient clinics of Selçuk University Faculty of Medicine Child Health and Disease department was determined as 20.000. There were 1054 patients diagnosed with primary immunodeficiency during the five-year period. According to this, primary immunodeficiencies accounted for about $1.75 \%$ of the patients admitted to the general outpatient clinics of Pediatrics and $25.7 \%$ of the 4100 patients who were followed in the Pediatric Allergy and Immunology outpatient clinic. During the 5-year follow-up, there were 287 patients diagnosed with THI. According to this, THI covers $0.47 \%$ of patients who are admitted to the polyclinics in total and $7 \%$ of patients who are admitted to the child allergy and immunology policlinic. The patients followed up with pre-diagnosis of primary immunodeficiency was $27.2 \%$.

$195(67.9 \%)$ of the patients were male and $92(32.1 \%)$ were female $(p<0.05)$. The $M / F$ ratio was 2.1 . The age of diagnosis ranged from 8 months to 48 months with a mean of $24.6 \pm 11.3$ months. Demographic characteristics of the patients are shown in Table 1. The duration between the complaints and the age of diagnosis was between 1 and 63 months and the mean age was $13.5 \pm 8.6$ months. Complaints of the patients were recurrent upper respiratory tract infection (URTI) 54.35\% (n: 156), lower respiratory tract infection (LRTI) 50.52\% (n: 145 ), sinusitis $41.26 \%$ (n: 118), recurrent otitis, $28.22 \%$ (n: 81 ), asthma finding $12.89 \%(n=37)$, allergic skin and rhinitis findings $10.45 \%$ (n: 30), gastroenteritis $6.96 \%$ (n: 20), urinary tract infection $4.18 \%$ (n: 12), and moniliazis was $3.83 \%$ (n: 11) (Table 2). URTI, LRTI and sinusitis were found significantly higher than other accompanying symptoms $(p<0.005)$.

The rate of consanguineous marriage was $30.0 \%$ in THI patients. The first degree was $2.8 \%$, the second degree was $14.6 \%$ and the third degree was $12.6 \%$. In 11 patients (3.83\%), there was a history of sibling death and no immunodeficiency was determined in the family. Growth retardation was detected in 16 patients (5.57\%). Anemia was found in 108 patients (37.63\%), neutropenia in 11 (3.83\%) and lymphopenia was found in 4 patients (1.39\%).

Levels of isohemaglutinin in patients with $A B O$ blood group antigens and lymphocyte proliferation response to mitogens were evaluated. 21 (7.31\%) patients had AB blood group, so the titer of isohemaglutinin could not be studied. The titers of isohemagglutinin was low in $52(18.11 \%)$ patients and returned to normal at later controls. The lymphoblastic transformation response of phytohemagglutinin was found normal in all children studied $(n=24)$. In 12 (4.18\%) patients, the antibody response to pneumococcal vaccine was found to be normal. Peripheral blood lymphocyte analyzes were compared with the normal values of healthy Turkish children in 147 (51.2\%) patients and the CD3, CD4, CD8, CD19 and CD16+56 levels were found normal.

103 of our patients (35.88\%) were diagnosed with asthma. Antihistaminic and/or local treatment was initiated in 18 (6.27\%)

\section{Table 1. Demographic characteristics of patients}

\begin{tabular}{lcc} 
& Mean \pm SD & Min.-Max. \\
\hline The age of diagnosis (month) & $24.6 \pm 11.3$ & $8-48$ \\
The duration between the complaints & & \\
and the age of diagnosis (month) & $13.5 \pm 8.6$ & $1-63$ \\
The follow-up time (month) & $12.6 \pm 15.3$ & $3-52$ \\
The age of recovery (month) & $28.6 \pm 10.1$ & $5-60$ \\
\hline
\end{tabular}

SD: Standard deviation; Min.: Minimum; Max.: Maximum.

Table 2. Clinical features of patients

\begin{tabular}{lcc} 
Complaints & $\mathbf{n}$ & $\%$ \\
\hline URTI & 156 & 54.35 \\
LRTI & 145 & 50.52 \\
Sinusitis & 118 & 41.11 \\
Recurrent otitis, & 81 & 28.22 \\
Asthma & 37 & 12.89 \\
Allergic skin and rhinitis findings & 30 & 10.45 \\
Gastroenteritis & 20 & 6.96 \\
Urinary tract infection & 12 & 4.18 \\
Moniliazis & 11 & 3.83 \\
\hline
\end{tabular}

URTI: Upper respiratory tract infection; LRTI: Lower respiratory tract infection.

Table 3. The main Ig deficiencies of the patients at the time of diagnosis

\begin{tabular}{lcc} 
& n & $\%$ \\
\hline Isolated IgG decrease & 87 & 30.31 \\
$\lg A$ and IgG decrease & 77 & 26.82 \\
$\operatorname{lgG}$ IgA and IgM decrease & 67 & 23.34 \\
$\lg$ and IgM decrease & 30 & 10.45 \\
$\lg A$ and IgM decrease & 26 & 9.05 \\
\hline
\end{tabular}

patients due to allergic rhinoconjunctivitis and dermatitis. In 111 patients, positivitiy was found in specific IgE elevated levels and/or skin prick test. In 10 (3.48\%) patients, isoniazid treatment was started upon detection of elevation in tuberculin skin test.

The main Ig deficiencies of the patients at the time of diagnosis are shown in Table 3.

Although 90 (31.35\%) of our patients were called for outpatient check-ups, they did not come. Immunoglobulin levels could be controlled in 116 (40.41\%) patients. The patients were followed-up for 3-52 months (mean 14 months). 25 (8.71\%) patients' Ig levels reached at normal level in consistence with age after 12 months (Normal range: 5-31 months). Despite the follow-ups, in 91 (31.70\%) patients, low levels of Ig levels were maintained. In spite of 52 months, there was the patient who had low Ig level. Among these patients, 27 (9.40\%) of them had isolated IgG decrease, $10(3.48 \%)$ of them 
had isolated IgA level decrease ( 3 of them were selective), 6 (2.09\%) of them had isolated IgM decrease. $\lg A$ and $\lg G$ in 16 (5.57\%) patients, IgG and IgM in 15 (5.22\%) patients, lgG and IgM in 11 (3.83\%) patients and IgA and IgM continued to decrease in 6 (2.09\%) patients. In 19 patients, fluctuations in Ig levels were observed.

In the controls, it was found that $50.17 \%$ (n: 144) of the patients had URTI and $29.26 \%$ (n: 84 ) had pyogenic infections. Co-trimoxazole prophylaxis was started in 129 patients (44.94\%). In 11 patients (3.83\%), chronic lung findings (atelectasis in 3 patients, bronchiectasis in 3 patients and fibrotic changes in 5 patients) were detected with $\mathrm{CT}$ and/or HRCT. Two patients $(0.69 \%)$ were treated with IVIG at $400 \mathrm{mg} / \mathrm{kg}$ every 4 weeks for recurrent LRTI. Antituberculosis treatment was started in two of our patients who had joint tuberculosis and pulmonary tuberculosis.

\section{Discussion}

THI is the primary humoral immune deficiency, which is characterized by a lack of normal Ig production due to the delay of immune maturation. ${ }^{[8-10]}$ The widespread opinion is that the clinical presentation of the disease is not homogeneous but that its course is heterogeneous. Although a number of pathological mechanisms have been proposed, the causes of $\mathrm{THI}$ are not fully known. Delay in maturation of B cells, auxiliary T cell (CD4+) maturation defects, and irregularities between cytokines take place among these mechanisms. In a study, it was reported that there was no dysfunction in B lymphocytes in THI but deficiency of T helper cell function caused a decrease in lg synthesis. ${ }^{[1]}$ This theory was supported by defect in CD4+ T cell numbers and functions, although B cell numbers and functions were normal. ${ }^{[4]}$ Recent studies have shown that cytokines have an important role in the pathogenesis of THI. Kowalczyk et al. found that TNF- $\alpha$, TNF- $\beta$, IL-10 production increased in patients with THI and there was no significant change in the release of other cytokines. ${ }^{[12]}$

Although the incidence of this disease group is unknown in our country, the high rate of consanguineous marriages constitutes a significant risk for these diseases. Relative marriages increase the risk of autosomal recessive and multifactorial diseases. ${ }^{\left[{ }^{[13]}\right.}$ In Asia and Africa, consanguinity is common for social and cultural reasons. ${ }^{[14,15]}$ The frequency of consanguineous marriages in Middle Eastern Muslims varies between 20-70\%. ${ }^{[16]}$ This situation is still a problem in our country. In our series, consanguineous marriage was found to be high in patients with THI (30.0\%).

Although there are various studies on the frequency of THI, it continues to be discussed. The incidences were found to be different in studies among various centers. The real incidence is not known due to the fact that most of the patients are asymptomatic or the cases of severe infection are rare. Some of the researchers report that THI rarely appears. Some suggest that THI cannot be detected sufficiently in clinical practice. ${ }^{[4-6,17-19]}$ Tiller and Buckley detected THI in 11 of 10 thou- sand patients. ${ }^{[6]}$ Dressler et al. similarly identified 5 cases in more than 8000 samples in 11 years. ${ }^{[17]}$ Walker et al. reported definite THI (1.5\%) in 15 of 2468 patients in 10 years, and probabale THI in 25 of them. ${ }^{[18]}$ This indicates that the incidence is about $21-61$ in 1,000,000 live births. ${ }^{[3]} 35$ of the 1632 infants referred to the Canadian Immunology Clinic were diagnosed with THI (2.1\%). ${ }^{[17]}$ In the study conducted by Kütükçüler et al., they found a rate of $12.5 \% .{ }^{[20]}$ In our study, THI rate was found as $27.22 \%$. The inconsistency of incidences in reports from various centers can be explained by different study populations and differences in the diagnostic criteria of this disease. The height of our rate can be explained by the fact that we are an immunology center and that children who are ill frequently can apply directly.

The heredity of the disease is not completely known. In the literature, it is reported that the patients with THI are predominantly male. In two studies, the ratio of male/female ratio has been found as $2 / 1 .{ }^{[19,21]}$ In our study, $69.94 \%$ of the cases were male, in accordance with the literature. When the symptom ages of the patients were examined, it was found that the symptom age of the patients diagnosed with $\mathrm{TH}$, was median 9 months in the study performed by Doğu et al. ${ }^{\left[{ }^{12]}\right.}$ In our study, the age of diagnosis ranged from 8 months to 48 months with a mean of $24.6 \pm 11.3$ months. This may be explained by the late referral of patients to our center. The fact that the peirod between the complaints and the diagnosis age was 13.5 \pm 8.6 months supported this idea.

THI's clinical characteristics vary widely from patient to patient. It may cause severe recurrent infections while seen without any symptoms. ${ }^{[3,6]}$ In the study of 40 cases with Kilıç et al., the most common complaints were the recurrent respiratory tract infection, otitis media, bronchitis, asthma and recurrent gastroenteritis. ${ }^{[19]}$ Doğu et al. reported similar results in their studies. ${ }^{[21]}$ In our study, these two studies showed similarity with the results. Invasive infections have been reported in two separate studies..$^{[19,21]}$ In the study of Dalal et al., meningitis was detected in one patient. ${ }^{[4]}$ In our study, we found sepsis in two $(0.69 \%)$ patients and meningitis in one $(0.34 \%)$ patient. This may be explained by the lower socioeconomic status of our patient population and poorer hygiene conditions.

The rate of atopic diseases is not significant in many series. ${ }^{[4,6]}$ However, Fineman and his friends in their study, defined food allergy and increase in IgE levels in patients with THI. ${ }^{[22]}$ Today, Walker et al. reported atopic disease or food allergy symptoms in 12 of 15 patients. ${ }^{[18]}$ In another study, 13 of 40 patients (32.5\%) had allergic symptoms including allergic bronchitis and atopic dermatitis. ${ }^{[19]}$ In another study, 14 of the 30 patients $(46.6 \%)$ had asthma and other allergic diseases. ${ }^{[20]}$ We found similar findings in our study. A total of 103 (35.88\%) patients were admitted with symptoms of asthma such as wheezing, coughing and wheezing, and 18 (6.27\%) patients with other allergic symptoms such as allergic rhinitis and atopic dermatitis.

Transient neutropenia is one of the rarely seen hematological 
abnormalities in THI. Tiller et al. in their study, they found temporary neutropenia in 2 patients $(18.1 \%) .{ }^{[6]}$ Dalal et al, in their study again, found neutropenia in two patients. ${ }^{[4]}$ In our series, 108 patients (37.63\%) had anemia, 11 (3.83\%) had neutropenia and $4(1.39 \%)$ had lymphopenia. Patients with THI should be followed up with complete blood count considering that there may be hematological abnormalities.

Even though THI has been known for a long time, there has not been enough information about the long-term outcome of these patients until recent years. In the prospective evaluation of these infants, normal Ig levels were found to reach in 30-40 months. Dalal and his colleagues followed 35 children with hypogammaglobulinemia for 10 years and showed that all other patients, except for three patients, reached normal IgG levels in 6-100 months. ${ }^{[4]}$ In the study of Kılıç et al., 40 patients with THI were evaluated prospectively and they showed that 33 of them had normalized Ig levels. ${ }^{[19]} 53 \%(n=16)$ of the patients reached normal Ig levels before 36 months, and the improvement was achieved in 5 patients (20\%) after 36 months (41-66 months). 9 patients with a average follow-up of 16 months have been reported with low lg levels. In the study conducted by the Doğu et al., patients were followedup for 5 to 28 months, and 21 (70\%) patients were reported to have normal levels consistent with age approximately at the age of 27 months, while improvement was monitored before 36 months of age in 16 of the 21 patients. ${ }^{[21]}$ In our series, patients were followed-up for 3-52 months (mean 14 months). In $25(8.71 \%)$ patients, Ig levels reached normal levels that were compatible with age after 12 months. In 91 (31.70\%) patients, a low level of IgG levels was observed despite the follow-up. In this study, according to the records of our patients, we found that $8.71 \%$ of THI patients improved with one year follow-up. This low rate can be explained by the shortness of our average follow-up periods.

In most patients with THI, normal or near-normal tetanus and diphtheria toxids have been reported to have an antibody response. In some cases, the level of isohemaglutinin was found to be in the normal range according to the age before the Ig levels were normal. ${ }^{[18,23]}$ Cano et al. reported that 11 of 12 patients with $\mathrm{THI}$ had no specific antibody response to the respiratory tract viruses panel despite repeated URTIs before 17 -month. ${ }^{[24]}$ In the study of Kılıç et al., 40 of the 40 patients had specific antibodies against polio virus antigens and they found antibody forming capacity against $\mathrm{ABO}$ blood group antigens in 39 patients. ${ }^{[19]}$ In our study, the titers of isohemagglutinin was low in 52 patients $(18.11 \%)$ at baseline and returned to normal at later controls. The response of phytohemagglutin to lymphoblastic transformation and response to pneumococcal vaccine was found to be normal in all studied children. These findings are consistent with the literature.

In general, supportive treatment and appropriate antimicrobial therapy for specific infections are sufficient in these patients. Although IVIG replacement therapy is not usually required, treatment of Ig may be considered in the presence of refractory infection to severe or conventional treatment. ${ }^{[3,4,24]}$ The aim of IVIG treatment is to help reduce the frequency and severity of infections. In the study performed by Kılıç et al., two (5\%) patients underwent IVIG treatment for about a year and in the follow-up they found that the levels of immunoglobulin returned to normal. ${ }^{[19]}$ In the study conducted by Doğu et al., two $(6.6 \%)$ patients were treated with IVIG and they discontinued the treatment when their immunoglobulin levels improved before 36 months. ${ }^{[21]}$ In our study, two $(0.69 \%)$ patients with recurrent pneumonia were treated with IVIG. Our practice was similar to the rates reported in other studies.

In studies in which patients with THI have been examined whether the patients have undergone recurrent infections in their follow-up have not been fully reported. Patients with recurrent respiratory or middle ear infections may benefit from prophylactic antibiotic treatment. Co-trimaxazole prophylaxis was initiated in 129 (44.9\%) of our patients. Antituberculosis treatment was started in two of our patients who had joint tuberculosis and pulmonary tuberculosis.

Complications may occur in patients due to recurrent respiratory tract infections. The earlier it is diagnosed, the more possible to reduce these complications. We found chronic lung findings in 11 (3.83\%) patients with THI. This is seen in diseases in which diagnosis is difficult and diagnosis is delayed. Pediatricians should not forget the imaging modalities as well as immunodeficiency screening panels in patients with recurrent lower and upper respiratory tract infections. For patients with normal CT, HRCT should be performed if necessary.

As a result, $\mathrm{THI}$ is usually a self-recovering disease around three years of age. Different results have been found in the literature on the age of recovery of immunoglobulins and the reason for this has not been elucidated yet. Long-term prospective studies are needed for this. Other causes of hypogammaglobulinemia must certainly be excluded. In order to prevent complications such as chronic lung disease and to reduce morbidity, it is important to follow up the cases regularly

Conflict of interest: There are no relevant conflicts of interest to disclose.

\section{References}

1. Gitlin D, Janeway CA: Agammaglobulinemia: Congenital, acquired and transient forms. Prog Hematol 1956; 1: 318.

2. Ochs HD, Stiehm ER, Winkelstein JA. Antibody deficiency. In: Stiehm ER, Ochs HD, Winkelstein JA, (eds). Immunologic Disorders in Infants and Children. $5^{\text {th }}$ edition: Philadelphia. Elsevier Saunders;2004.p.357-73.

3. Wilson CB, Lewis DB, Penix LA:The physiologic immunodeficiency of immaturity. In Stiehm ER(ed): Immunologic Disorders in Infants and Children. Philadelphia, WB Saunders, 1996,p:253.

4. Dalal I, Reid B, Nisbet-Brown E, et al: The outcome of patients with hypogammaglobulinemia in infancy and early childhood. J Pediatr 1998; 133: 144-6.

5. McGeady SJ: Transient hypogammaglobulinemia of infancy: Need to reconsider name and definition. J Pediatr 1987; 47: 110. 
6. Tiller TL, Buckley RH: Transient hypogammaglobulinemia of infancy: Review of the literature, clinical and immunologic features of 11 new cases, and long-term follow-up. J Pediatr 1978; 92: 347.

7. Primary immunodeficiency diseases. Report of an IUIS Scientific Committee. International Union of Immunological Societies. Clin Exp Immunol 1999; 118 (Suppl 1): 1-28.

8. Luzi G, Pesce AM, Rinaldi S: Primary immunodeficiencies in Italy. Data revised from the Italian Register of Immunodeficiencies-IRID (1977-1988). Immunol Clin 1989; 8(1): 45-54.

9. Ryser O, Morell A, Hitzig WH: Primary immunodeficiencies in Switzerland: First report of the national registry in adults and children. J Clin Immunol 1988,8(6): 479-85.

10. Affentranger $P$, Morell $A$, Spath $P$, Seger $P$ : Registry of primary immunodeficiencies in Switzerland. Immunodeficiency 1993; 4: 193-5.

11. Siegel RL, Issekutz T, Schwaber J, et al: Deficiency of T helper cells in transient hypogammaglobulinemia of infancy. N Engl J Med 1981; 305: 1307.

12. Kowalczyk D, Mytar B, Zembala M: Cytokine production in transient hypogammaglobulinemia and isolated IgA deficiency. J Allergy Clin Immunol 1997;100: 556.

13. Francisco A, et al. Update on primary immundeficiency diseases. J Allergy Clin Immun 2006;117: 435-41.

14. Stiehm ER, Ochs HD, Winkelstein JA: Immunologic disorders: general consideration. In Immunologic Disorders in Infants and Children, ER Stiehm, HD Ochs, JA Winkelstein (eds). USA, Elsevier Saunders, 2005, pp 289-355.

15. Bittles AH, Mason WM, Greene J, Rao NA: Reproductive behavior and health in consanguineous marriages. Science 1991; 252: 789-
94.

16. Bittles A: Consanguinity and its relevance to clinical genetics. Clin Genet 2001;60: 89-98.

17. Dressler F, Peter HH, Muller W, et al: Transient hypogammaglobulinemia of infancy: Five new cases, review of the literature and redefinition. Acta Paediatr Scand 1989;78: 767.

18. Walker AM, Kemp AS, Hill DJ, et al: Features of hypogammaglobulinemia in infants screened for immunological abnormallities. Arch Dis Child 1994;70: 183.

19. Kılıç SS, Tezcan I, Sanal Y, Metin A, Ersoy F. Transient hypogammaglobulinemia of infancy: clinical and immunological features of 40 new cases. Pediatr Int 2000;42: 647-50.

20. Kutukculer N, Aksu G. Frequency of primary immundeficiencies diagnosed in 10 years in a pediatric immunology department in turkey (480 cases). XIIth Meeting of the European Society for Immunodeficiencies (ESID). 4-7 october 2006, Budapest, Hungary. p:229.

21. Dogu F, Íkinciogulları A, Babacan E. Transient hypogammaglobulinemia of infancy and early childhood: outcome of 30 cases. Turk J Pediatr 2004;46: 120-4.

22. Fineman SM, Rosen FS, Geha RS: Transient hypogammaglobulinemia, elevated immunglobulin E levels and food allergy. J Allergy Clin Immunol 1979;64: 216.

23. Vetrie $D$, Vorechovsky I, Sideras $P$, et al: The gene involved in $X$ linked agammaglobulinemia is a member of the src family of protein-tyrosine kinases. Nature 1993;361: 226.

24. Cano F, Mayo DR, Ballow M: Absent specific viral antibodies in patients with transient hypogammaglobulinemia of infancy. J Allergy Clin Immunol 1990;85: 510. 